レーザー解説

レーザー核融合におけるハイパワー 3 倍高調波変換

實 野 孝 久*

(1992年 3 月 5 日 受理)

\title{
Third Harmonic Conversion in High Power Glass Laser for Fusion
}

Takahisa JITSUNO *

(Received March 5, 1992)

\begin{abstract}
This paper deals with the third harmonic conversion technology on the high power glass laser for fusion application. The details of the fabrication and alignment procedures of a $36 \mathrm{~cm}$ diameter segmented KDP crystal cell with an index matching fluid, and the energy monitor system for third harmonic light without distortion on the beam patterns are described. The conversion efficiency from $1.05 \mu \mathrm{m}$ to $0.35 \mu \mathrm{m}$ was found to be $60 \pm 10 \%$ for 12 beams .
\end{abstract}

Key words: Third harmonic conversion, High power glass laser, Laser fusion, KDP crystal, conversion efficiency, Energy monitor system.

\section{1.はじめに}

最近の非線形光学の進歩は著しく, 広いパ ワーレベル・広い波長範囲で波長変換が可能と なっている。最近の話題となっている半導体 レーザーなどの低いパワーレベルでの波長変換 などは新しい方向であるが，ピークパワーの極 めて高い大口径のレーザーに拈ける高調波発生 も困難な技術である。本稿では核融合実験用 ガラスレーザーにおける大口径ハイパワー波長 変換技術を紹介する。

\section{2.ハイパワー波長变換}

本節ではレーザー核融合用ガラスレーザーの 使用目的と必要とされる性能について簡単にふ
れ, 大阪大学レーザー核融合研究センターの激 光XII号ガラスレーザーを例として，使用され ている波長変換技術について述べる。

\section{1 レーザー核融合}

レーザー核融合では，燃料である重水素 (D) と三重水素 $(\mathrm{T})$ を閉じ込めたカプセル (夕ー ゲット)を強力なレーザー光で照射し，噴出す るプラズマの反作用により燃料を超高密度・高 温度に圧縮 (爆縮)して, 核融合反応を圧縮コア の内部で発生させる。照射するレーザー光の ターゲット上での分布や, ターゲットそのもの に不均一があると爆縮コアの形が变形し, コア の温度と密度が低下するため, 燃料の点火条件 を得るために必要なレーザーのエネルギーが大

*大阪大学レーザー核融合研究センター (†565吹田市山田丘 2-6)

* Institute of Laser Engineering, Osaka University (2-6 Yamada-Oka, Suita, Osaka 565) 
幅に増加する。このため, ターゲットの外側に 外球を設けてその内面にレーザー光を照射し， 発生するX線を用いてターゲットを照射する間 接照射方式が考案された。この間接照射方式で は, レーザー光は外球内面の高密度プラズマを 加熱する必要があり，プラズマの高密度領域ま で到達し得る短波長レーザー光が必要となって きた。また, 直接照射方式に扔いて, 強力なレー ザー光とプラズマとの相互作用により発生する エネルギーの高い高速電子の発生を抑制するた めにも，短波長のレーザーが適している。この ような理由で，世界の核融合実験用レーザー装 置はすべて短波長のエキシマレーザーか1）， あ るいは近赤外領域のガラスレーザー光を波長変 換により短波長にして使用している ${ }^{2,3)}$ 。

\section{2 核融合用ガラスレーザー装置}

核融合実験には短いパルス幅 $($ ～ $3 \mathrm{~ns})$ で大き な出力エネルギー $(10 〜 100 \mathrm{~kJ})$ を有するハイパ ワー (50 100TW ) のレーザー装置が必要であ り，Ndを含有したレーザーガラスを媒質とす るガラスレーザーが主として使用されている。 レーザー光を増幅する増幅器には, 非線型屈折 率の小さい燐酸ガラスのロッドまたはディスク と，これを光励起するフラッシュランプが組み 込まれている。このフラッシュランプにキャ パシターバンクに蓄えたエネルギーを $300 \mu \mathrm{s}$ 程 度の時間で放電することにより，レーザーガラ スを光励起している。増幅されるレーザー光は レーザーガラスの利得の中心波長に合わせるた め, YLF (Yttrium Lithium Fluoride) 結晶を用い たモードロックーQスイッチ発振器により発生 される。レーザーのパルス幅は発振器の動作範 囲 $(100 \mathrm{ps} \sim 1 \mathrm{~ns})$ で発生するガウス型パルスと, 波形成形器で合成される任意の形の波形が使用 可能である。前置増幅器列で増幅されたレー ザー光は，ビーム分岐部で反射鏡により 12 本に 分割された後, ターゲットチェンバーまでの各 ビームの光路長差を補正した上で主増幅器列に 入射する。主増幅器列にはロッドおよびディス ク型の増幅器と, ビーム径を増大しながらビー
ムパターンの回折による劣化を防止するために イメージ転送を行う空間フィルター，後段から の反射光がシステムを逆進することを防止する ファラデー回転子などが配置されており，レー

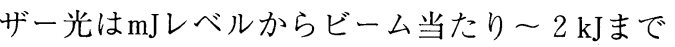
増幅される。増幅器列の最終空間フィルターの 出口でレーザー光の直径は約 $35 \mathrm{~cm}$ であり, ビー ムはこのまま各ビーム 4 枚のターニングミラー によりターゲットチェンバーまで導かれる。最 終ミラーによりターゲットの中心に向かうよう に方向を調整されたビームは, ターゲットチェ ンバー上の集光レンズの直前に置かれた波長変 換用 $\mathrm{KDP}$ 結晶により，2 倍または 3 倍高調波(波 長 $\lambda=0.53$ まな $0.35 \mu \mathrm{m})$ に変換される。波 長変換されたレーザー光は大口径の非球面レン ズによりターゲット上に絞りこまれる。ター ゲットの直径は0.5〜 $1 \mathrm{~mm}$ で，レーザー光をで きるだけ均等に照射するため, ターゲットは集 光ビームに内接する位置に置かれる。レーザー システムの全長は発振器から夕ーゲット中心ま で約 $280 \mathrm{~m}$ あるため, 僅かのビームの指向性の 変化でもビーム位置は大きくずれてしまう。そ こでシステム内のビームの各折り曲げ点では, 反射鏡を透過する光を使ってビームの位置を検 出し，所定の位置からずれている場合にはその 上流のミラーを調整するレーザーアラインメン トシステムが設置されており，集光部にも夕ー ゲットからの反射光の方向が，入射光の指向性 の誤差により変化することを利用した集光アラ インメントシステムが設置されている。これら のアラインメントシステムにより, KDP上での ビームの方向 (角度) 変動はアラインメント終了 時で $\pm 10 \mu \mathrm{rad}$ 以内，24時間以内での安定性士 $50 \mu \mathrm{rad}$ 以内と言う良好な值となっている。ま た，KDP結晶を用いて高い波長変換効率を得る ためには, 光軸に対して結晶を高い精度で設置 しなければならない。KDP結晶では結晶の厚み と使用するレーザー光の強度により定まる許容 角度 (通常 $30 \sim 60 \mu \mathrm{rad}$ ) 以内に結晶セルの角度 を調整する必要があり, 低エネルギーのレー ザーショットを用いて調整が行われている。 


\section{3 . 波長変換技術}

核融合用ハイパワーガラスレーザーの高調波 発生には，大型の結晶を製作・加工できるKDP が非線形光学結晶として使用されており, 結晶 セルと屈折率整合液を使用するウエットセル方 式と，屈折率整合液を使用しないドライセル方 式がある。本節では激光XII号ガラスレーザー 装置に使用されているウエットセル方式の詳細 を紹介する。

\section{1 高調波発生の原理}

KDPのような中心対称性のない原子配列の結 晶では, 強力な電磁波が伝播すると結晶内に 偏った分極を生じる。この分極のフーリエ成分 として，結晶内には入射波と異なった周波数の 波が複数存在することになる。これらの結晶中 を伝播する波の相互のエネルギーのやり取りを 記述するのが非線型相互作用の基礎方程式であ

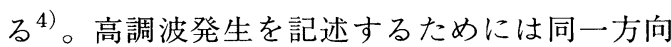
に進む $\omega_{1}, \omega_{2}, \omega_{3}$ の 3 つの波を考え，

$$
\omega_{3}=\omega_{1}+\omega_{2}
$$

であるとして，その電界を $E_{1}, E_{2}, E_{3}$ で表すと，

$$
\begin{aligned}
& d E_{1} / d z=-\gamma_{1} E_{1}-i k E_{3} E_{2} \exp (-i \Delta k z) \\
& d E_{2} / d z=-\gamma_{2} E_{2}-i k E_{3} E_{1} \exp (-i \Delta k z) \\
& d E_{3} / d z=-\gamma_{3} E_{3}-i k E_{1} E_{2} \exp (-i \Delta k z)
\end{aligned}
$$

ただし $\quad \Delta k=k_{3}-k_{2}-k_{1}$

$$
k_{i}=d_{\text {eff }} \omega_{i}\left(\mu_{0} / \varepsilon_{i}\right)^{1 / 2}
$$

$d_{\mathrm{eff}}$ : 非線形光学係数, $\gamma$ : 損失

で表される。これらの式から明らかなように， $\Delta k=0$ の時に相互作用が最も効率よく行われ ることが判る。KDP結晶は入射光の偏光方向に 対する複屈折と, 波長に対する屈折率の色分散 を持っており，これらをうまく組み合わせると使 用する波長 (基本波と高調波)に対して $\Delta k=0$ となる位相整合条件を得ることができる。また， 相互作用は結晶の厚みにも依存するため，使用
するレーザー光の強度により最適の厚みを決定 する必要がある。この目的のため, 上記の微 分方程式を計算機上で解くことにより，結晶の 厚みや偏光角を変えた場合の変換効率を理論的 に求めることが出来る。

\section{2 波長変換方式}

KDP結晶を使用した 3 倍高調波 $(3 \omega)$ 变換に も, 幾つかの方式が存在している。まず, 位相 整合の取り方により，基本波 $(\omega)$ と 2 倍高調波 $(2 \omega)$ を KDP 結晶の常光線軸 ( $o$ 軸) の方向に偏 光して入射するタイプI と, $\omega$ を 0 軸方向に入 射し， $2 \omega$ を異常光線軸 ( $e$ 軸) 方向に入射する タイプII 方式である ${ }^{5)}$ 。タイプII の方が夕イ プIより角度調整精度が緩く, 切り出す結晶 も小さくてすむことから，激光XII号では夕 イプII が使用された。また， $3 \omega$ の発生には $2 \omega$ 発生用と $3 \omega$ 発生用の 2 枚の結晶が必要 であり，その相互関係より(a) Angle-Detuning, (b) Polarization-Mismatch, (c) PolarizationBypass の 3 つの方法がある ${ }^{5)}$ 。激光XII号では 結晶の間に波長板を必要とせず，タイプ II の結 晶が使用できる (b)の方式が採用された。

\section{3 大型 $\mathrm{KDP}$ 結晶}

KDPは水溶性の正方晶の結晶であるため，他

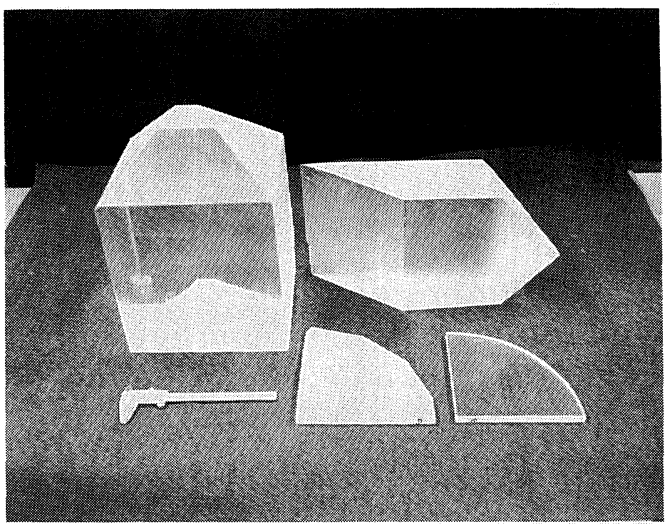

Fig.1 KDP crystals under cutting, shaping and polishing. 


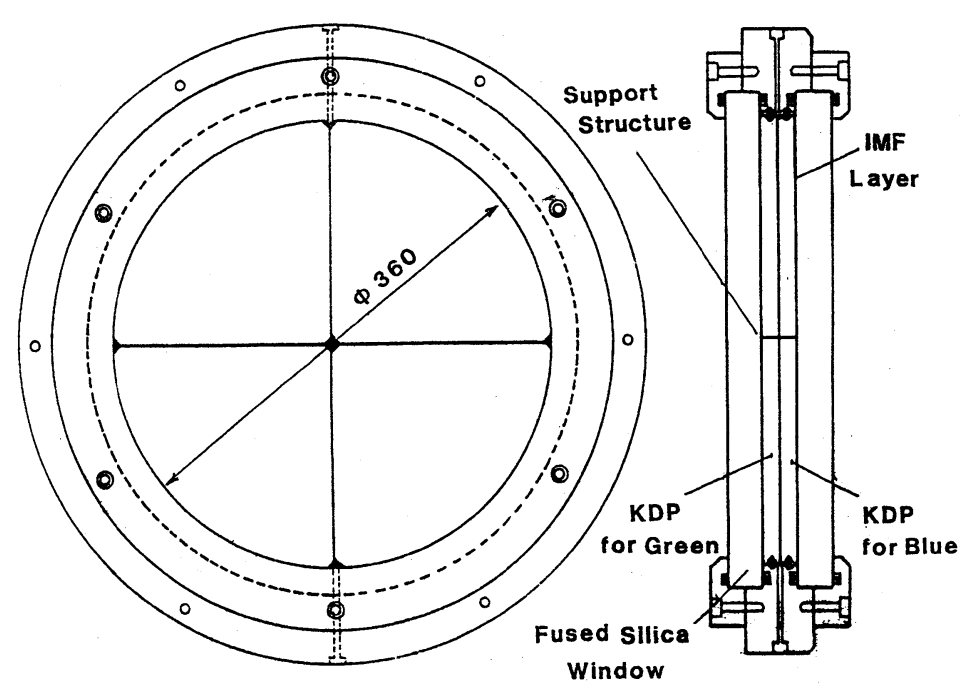

Fig.2 Schematics of the KDP cell for the Gekko XII glass laser.

の溶融法により育成される結晶と比べて，比較 的容易に大型結晶を育成できる。最初に良質の 種結晶を育成し，KDPを溶解した水溶液中で温 度降下法により，大型結晶に育成する。激光 XII号で使用されたKDP結晶は，当センターの 長年の努力の結果開発された均一性・レーザー ダメージ耐力に優れたものであったが，激光 XII号の $3 \omega$ 化が予算化された時期 (1986年)に は，単一結晶で有効径 $38 \mathrm{~cm}$ を得ることができ ず，4 分割の 8 枚の結晶をセルの中で組み合わ せる方式が採用された。この選択は同時に今後 のより大口径 $(60 \mathrm{~cm}$ 以上) の結晶セルを製作す る場合に備えて, 組み合わせ結晶の基礎技術を 開発するためでもあった。このため，大型結晶 から結晶板を切り出し，レーザー装置により基 準結晶との比較で光軸測定を行う方法が開発さ れた ${ }^{6)}$ 。各分割結晶の角度許容誤差は $2 \omega$ 用土 $60 \mu \mathrm{rad}$ 以内， $3 \omega$ 用 $\pm 30 \mu \mathrm{rad}$ 以内で，角度修 正と表面研磨は特別に開発されたダイアモンド ターニングマシンを使用して行われた。結晶の 表面粗さは $0.02 \mu \mathrm{m}$ 以内に仕上げられた。結晶 のブールおよび切り出し, 整形, 研磨中の結晶 板の写真をFig. 1 に示す。

\section{4 大型 KDP セルの構造}

前節で述べたように，激光XII号の波長変換 には $2 \omega \cdot 3 \omega$ 発生用の各々 4 枚づつの結晶板を 使用しなければならないために，合計 8 枚の四 分円形の結晶を保持するセルが必要である。 各々の結晶板の保持精度は, 波長变換の効率に 影響を与えない $\pm 30 \mu \mathrm{rad}$ 以内になっている必 要があり, $100 \mu \mathrm{m}$ の厚みのステンレス板のス ペーサーにより結晶と空ガラス，抄よび結晶相 互の間の屈折率整合液の厚みを保つ構造が採用 された。結晶の厚みは $2 \omega$ 用， $3 \omega$ 用共に $12 \mathrm{~mm}$, セルの有効径は $36 \mathrm{~cm}$ 以上, 波面歪みは非球面 成分で $\lambda / 4$ 以下を目標としたため, 入射側空 (材 質BK-7) および出射側空 (溶融石英)の厚みは $35 \mathrm{~mm}$ とした。セル構造をFig. 2 に示す。この 構造のため空は結晶保持と波面の維持を同時に 行わなければならず，後述するような特殊な波 面調整の手法を開発する必要が生じた。屈折率 整合液は, 誘導ラマン散乱の発生閾值の高い炭 酸プロピレンを使用したが，このために液の シールに用いたOリングは，特殊なシリコンゴ ム製を使用しなければならなかった。組み立 てではセルの寸法, 各結晶の厚みとOリングの 直径を測定し, 空の締め込み量を算出した。ま 


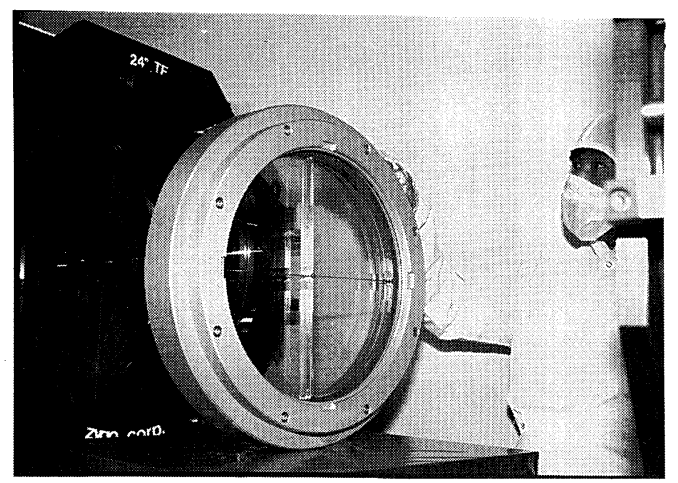

Fig.3 KDPcell for third harmonic generation.

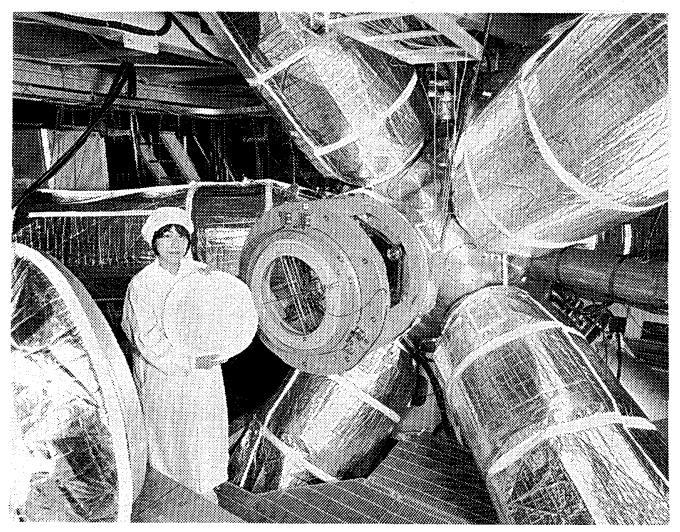

Fig.4 Target chamber with a $3 \omega$ irradiation system. Half of 12 beams ( 6 beams) are seen in the photograph.

た，結晶表面が粗かったため，屈折率整合液を 後から注入するとどうしても気泡が残ったた め，液中で結晶を組み上げる方法を採用した。 4 分割結晶の間には誘導ラマン散乱を防止する ための遮光帯をセルの厚みいっぱいに挿入し， セルの入射と出射空の外側には, 結晶分割部に 光が当たらないようにするため,レーザー光を 吸収する十字形の遮光板を設けた。このKDP七 ルはターゲットチェンバーに取り付けられたレ ンズ駆動装置の外側に，KDP駆動装置により取 り付けられた。このKDP駆動装置の角度分解能

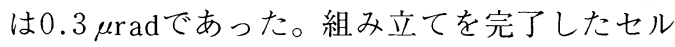
の写真をFig.3, ターゲットチェンバーに取り 付けられたKDP駆動装置と結晶セルおよび感光
紙に記録された $3 \omega$ 光パターンをFig. 4 に示す。

\section{5 エネルギーモニター系}

核融合実験では，ターゲットに照射するレー ザービームの強度を正確に調整し，照射の一様 性を得ることが重要であるが，このビームバラ ンスは高調波光で取られなければならない。し かし, 多数本の大口径のレーザービームの工ネ ルギーおよび波形を正確に測定するのは，一般 的な予想以上に困難な仕事である。特に, レー ザー光の分布に変化を与えずに計測を行うため には，特別の配慮が必要である。激光XII号で は高調波光のエネルギーと波形は, $\mathrm{KDP}$ 結晶セ ルの出力側空の表面反射を利用し, 最終の折り 曲げミラーを透過する光を用いて計測されてい る。Fig. 5 に測定系の配置図を示す。しかしこ の計測法では, 空の反射率やミラーの透過率が 空気中の湿度で変化したり, 低いエネルギーの 調整ショットでは基本波の強度が高調波に比べ て非常に強く，反射防止コートの反射率も基本 波の方が高いため, 反射された基本波が結晶内 を通過する時に高調波に変換されて測定誤差を 生じる。これらの問題を解決するため, セルの 出力側の空はコートを行わずに高調波光の反射 率を上げ，ミラーのコーティングも高調波の波 長を中心に広い波長範囲で一定の透過率を保つ ものを採用した。またこの計測法では，エネル ギーモニター系はKDPセルからの反射光のみな らず，ターゲットからの反射光も受けてしまう ため, 信号を時間分解計測する必要が生じる。 このような多数の信号の時間分解計測を精度良 く行うため, 時間ゲートを有する積分型の A/D 変換器 (CAMACシステム)が使用された。しか し, このA/D変換器は信号電圧が 1 ～ $2 \mathrm{~V}$ にな ると誤動作する特性が有るため, 電圧を落とし て計測する必要があり, 測定精度が十分に取れ なかった $(1 〜 2 \%)$ 。測定精度を向上するため， この測定系に外部高速ゲート回路を付加して使 用している。また，エネルギーモニターの絶対 較正は，基本波で40J程度の100psパルスを結晶 に入射し，発生する高調波光のエネルギーを， 


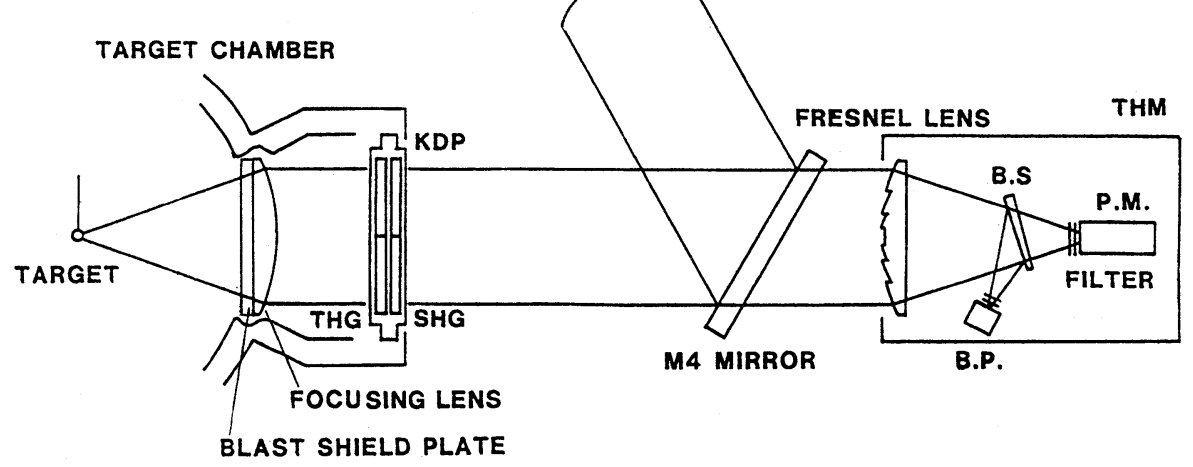

Fig. 5 Schematic diagram of the energy monitoring system.

誘電体多層膜をコートした波長選別板を使用し て測定して行っている。現在も $\mathrm{A} / \mathrm{D}$ 変換器のカ ウント数を 200 程度から 1000 に増加するため, 外部積分回路の導入等のテストが行われてい る。

\section{6 変換効率}

先に述べた非線形相互作用方程式からは, 最 適の入射強度では $80 \%$ を越える $3 \omega$ への変換効 率が得られるはずであるが，激光XII号に 12 個 の結晶を取り付けて最初に変換効率を測定する と，30〜40\%の効率しか得られなかった。この 原因を調査したところ，結晶の透過波面を良く するために, セルの空板の圧迫を緩くしており， 取り付け作業で結晶セルを動かしたために，空 を保持するOリングが空の自重のために変形 し，結晶を保持する空間隔が変化してしまった ものと判明した。このため急遽結晶セルを取り 外し, 透過波面より結晶の角度保持を優先して 空間隔を調整した結果, 12 ビームの平均で $60 \pm$ $10 \%$ 変換効率を得た。入射強度に対する実測 変換効率をFig. 6 に示す。変換効率が予測通り に得られていない理由についてレーザー部の光 学素子にかかる応力によるビームの偏光の劣化 と, ビームパス中の窒素分子の回転ラマン散乱 による偏光面回転について測定したが，明白な 偏光の劣化や回転は観測されなかった。このほ か実際の高出力ショットでは実験を始めてすぐ



Fig. 6 Conversion efficiency measured and calculated for $3 \omega$.

に, 結晶セル内に多数の気泡が発生し, 集光レ ンズに回折による損傷を生じ始めた。そのまま ショットを続けると損傷が進行し, 集光レンズ が真空応力で割れるため, ショットを中止して 原因調査を行った。その結果, 気泡は液中で結 晶セルを組み立てる際に混入した，僅かなダス トが原因であることが判明したため，全てのセ ルを再度分解・洗浄し, 組み立て完了後に清浄 な整合液を循環して,ダストを除去した。その 結果, 最終組み立てより 3 年以上を経過した現 在でも殆どのセルに気泡は発生していない。ま た透過波面についてもセルの空を圧迫する空抑 


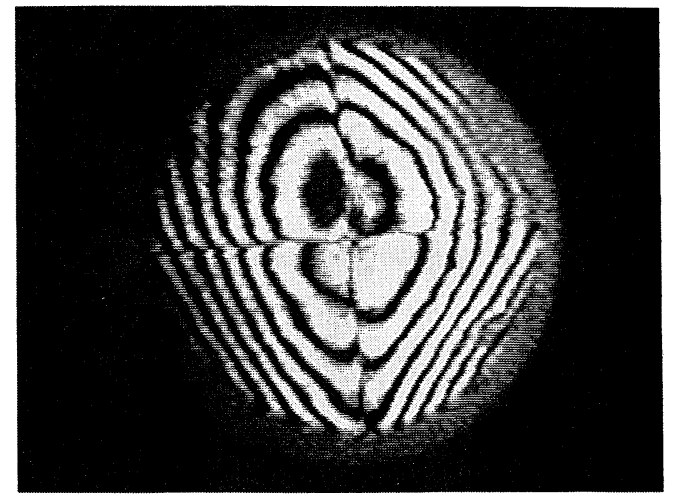

(a) Before improvement.

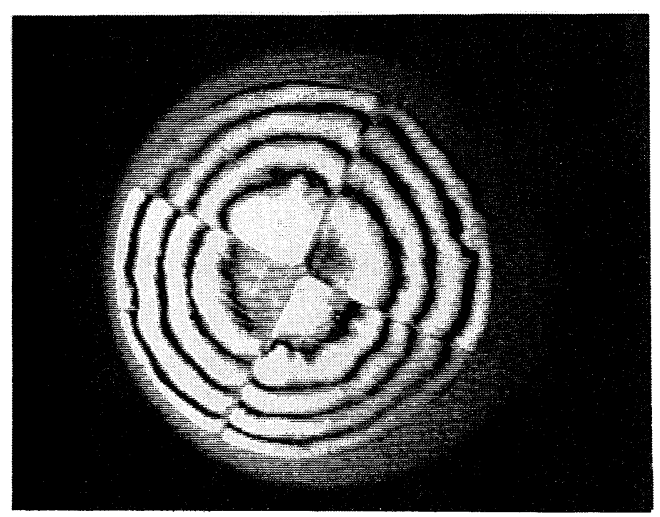

(b) After improvement.

Fig. 7 Improvement of the wavefront distortion in a segmented cell. (a) Before improvement; (b) After improvement.

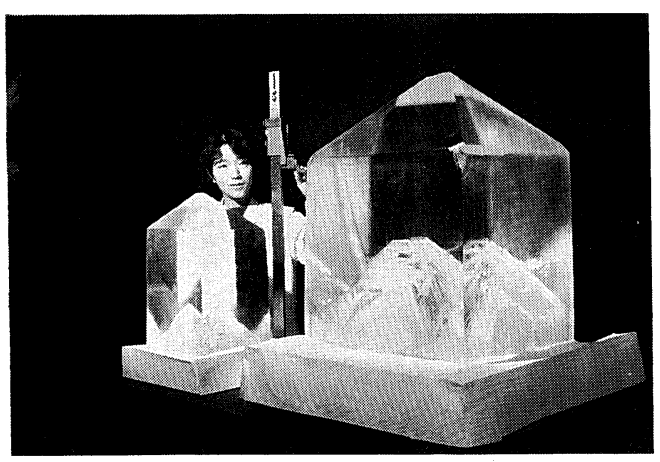

Fig. 8 Large scale KDP crystal of the monolithic structure in $40 \mathrm{~cm}$ diameter.
えとセル本体の間にスペーサーを挿入し，結晶 を保持するために生じる空の恋形を外部より補 正する方法を採用したところ，球面収差は含む が非球面収差の小さい透過波面が得られた。そ の調整前と完了後の透過波面をFig. 7 に示す。

\section{4. 現在の問題点と今後の方針}

以上述べて来たように，激光XII号では有効 径 $360 \mathrm{~mm}$ の世界最大の分割結晶・屈折率整合液 を使用した波長変換セルを使用して，3 倍高調 波が爆縮実験に定常的に使用されている。しか し現在の技術には，低い变換効率，大きい球面 収差, 集光パターン上の遮光帯による回折フリ ンジ等が含まれており，決して満足すべき状態 にはない。そこで現在, 上記の問題点を解決す るために $40 \mathrm{~cm}$ 級のモノリシック結晶が切り出 せる超大型結晶の開発が進んでおり，自重 $300 \mathrm{~kg}$ を越える結晶が量産されつつある。Fig. 8 にその結晶の写真を示す。写真の左側の結晶 が激光XII号の $3 \omega$ 化に使用されたものであり， 大型化の様子がわかる。このような大型結晶は 取扱, 切り出し, 軸測定, 光学研磨等どれをとっ ても従来に無い経験であるが，順調に技術開発 が進みつつあり, 数力月以内にモノリシックの 3 倍高調波発生用セルが完成する予定である。

また今後の激光XII号アップグレードに必要 とされる $60 \mathrm{~cm}$ 級のドライセルの基礎技術とし て, 結晶の光学研磨と反射防止コートについて も技術開発が進んでいる。

\section{謝辞}

本報告はレーザー核融合研究センターの多く のグループと関係企業の長年の努力の結果, 得 られた成果をまとめたものである。当セン ター・クリスタルグループ, 光学技術室, ガラ

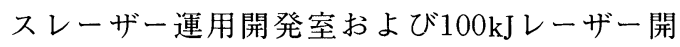
発委員会参加各社, 特にキャノン株式会社, キャ ノン販売株式会社, 御幣島化学株式会社, 株式 会社オプトケミカルの多大の貢献があったこと を申し添え, 紙面を借りて御礼申し上げる。 


\section{参 考 文 献}

1) L. A. Rosocha, R. G. Anderson, S. J. Czuchlewski, J. A. Hanlon, J. E. Jones, R. G, Jones, CLEO'89 Technical Digest, (1989) $M G-2$.

2) J. T. Hunt and D. R. Spec, Optical Engineering, 28 (1989) 461.

3) M. Nakatsuka, T. Jitsuno, T. Kanabe, S.
Urushibara, N. Miyanaga, S. Nakai, SPIE Proceedings 1411 (1991) 108.

4） A. Yariv, “光エレクトロニクスの基礎”，丸 善 1988 .

5) R. S. Craxton, Optics Communications 34 (1980) 474.

6）佐々木孝友, 横谷篤至, 山中龍彦, 山中千代 衛：レーザー研究，13 (1985) 44. 